Pomaskow J., The importance of law and economics in the contemporary economic reality, „Ekonomia i Prawo. Economics and Law”, Polszakiewicz B., Boehlke J. (ed.), Vol. 14, No. 2/2015, pp. 233241. DOI: http://dx.doi.org/10.12775/EiP.2015.014.

\title{
THE IMPORTANCE OF LAW AND ECONOMICS IN THE CONTEMPORARY ECONOMIC REALITY
}

\author{
SUMMARY
}

The law and economics movement can improve the functioning of companies doing business in the contemporary, rapidly changing, reality. The tensions between the idea of efficiency and the idea of justice ${ }^{1}$ cause difficulties in the application of tools which are proposed by the representatives of the law and economics movement in legal solutions. Economics proposes a new, fresh look at the law, which makes it easier to assess and influence the growth of its transparency. Perspective can therefore be useful for subjects who create and use the existing regulations.

Keywords: law and economics, efficiency of law, justice, business activity JEL Classification: K00, K20

" Joanna Pomaskow, Nicolaus Copernicus University, Faculty of Economic Sciences and Management, Department of Economics, ul. Gagarina 13A, 87-100 Torun, Poland, phone: +48 793613 002, e-mail: j.pomaskow@doktorant.umk.pl.

${ }^{1}$ Legal justice is discussed here. It should be distinguished from moral justice which is a natural consequence of human integrity. For more see: K. Kalka, Sprawiedliwośc $i$ sprawności spoteczne wedtug św. Tomasza z Akwinu, Wydawnictwo Uczelniane WSP w Bydgoszczy, Bydgoszcz 1994. 


\section{INTRODUCTION}

The main purpose of the discussion is an assessment of the significance of the movement law and economics in the modern market economy. The dynamically changing reality and limited resources determine the need to develop the traditional approach to modern law and to study its norms in economic terms. This is not easy because of the amazing diversity of views among the representatives of the law and economics movement, but, at the same time, it is necessary so as to achieve the proper shape of legal and economic institutions which have a major impact on the operation of enterprises in the modern market economy.

\section{THE CURRENT STATE OF KNOWLEDGE}

The analysis of regulation by law in the economic aspect is not a new phenomenon: it came into being together with the emergence of the school of law and economics at the University of Chicago in the 1970s. Law and economics was the subject of philosophical, political, and later, economic works by such thinkers as: Aristotle, Plato, Thomas Aquinas, Niccolo Machiavelli, Adam Smith, and Jeremy Bentham.

\section{THE METHODOLOGY OF RESEARCH}

To achieve this ambitious research objective, to which the layout of this article is subordinated, it has been decided to apply the methods of analysis and criticism of the literature. The interdisciplinary nature of the law and economics movement has resulted in the necessity of referring to the current state of knowledge by delving into the literature in the field of economics and law.

\section{THE RESEARCH PROCESS}

The first part of the article focuses on the basic premise of the researched movement, which is economic efficiency, and then indicates the ostensibility of the dissonance between the movement and justice, as having fundamental significance for the law. The considerations end in an indication of the role of law and economics in the modern, dynamically changing, economic reality. 


\subsection{ECONOMICS EFFICIENCY AS THE MAIN ASSUMPTION OF THE LAW AND ECONOMICS MOVEMENT}

Law is a kind of management system. Analysis of the system can refer to the operation, within its framework, of institutions and multi directional links existing among them, evaluated in terms of the degree of efficiency of the functions performed by them ${ }^{2}$.

Legal institutions are a group of normative statements which make up a whole, according to the criterion of the subject of regulation. Only a given legal relationship can be such a subject ${ }^{3}$. In economic sciences, institutions are understood in a similar way. In this case, however, the concept in question undergoes extension also by institutions, having an informal character. They can complement formal institutions, but also stand in conflict with them ${ }^{4}$.

Effective interpretation of the law is only possible by using the appropriate tools. Modern economic reality which is changing dynamically forces the extension of the catalogue of interpretations of the law by the interpretations proposed by the representatives of the law and economics movement, in the form of cost-benefit analysis and game theory ${ }^{5}$. Economic efficiency is not the only value of the law and, importantly, a threat to justice ${ }^{6}$, which will be discussed later in this paper. Moreover, it is also not an unambiguous notion, but multidimensional. Paul Samuelson and William Nordhouse define it as "the process by which society derives from the consumers their

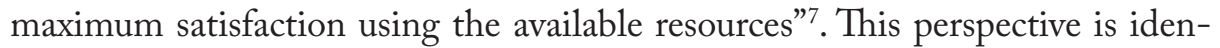
tified by the authors as the Pareto efficiency. Another criterion of efficiency used in economic sciences, which are an integral part of welfare economics, is the Kaldor-Hicks efficiency in the marginal analysis efficiency which will be discussed later in this paper.

2 M.J. Golecki, Między pewnościq a efektywnościq. Marginalizm instytucjonalny wobec prawotwórczego stosowania prawa, Wolters Kluwer, Warszawa 2011, p. 122.

3 S. Ehrlich, Wstęp do nauki o państwie i prawie, PWN, Warszawa 1971, p. 99.

${ }^{4}$ T. Gaweł, M. Klimczak, Pojęcie instytucji w prawie i ekonomii, „Ekonomia i Prawo”, Vol. 1, No. $1 / 2005$, pp. $73-86$.

5 The subject of interest in the game theory is the choice of the optimal solution in the event of a conflict of interest. This theory turns out to be useful for a better understanding of some legal institutions. For more on this topic see: R. Cooter, T. Ulen, Ekonomiczna analiza prawa, C.H. Beck, Warszawa 2011, pp. 43-47 and D. Baird, R. Gertner, R. Picker, Game Theory and the Law, Harvard University Press, 1998.

${ }^{6}$ J. Stelmach, B. Brożek, W. Załuski, Ekonomiczna efektywnośc, [in:] J. Stelmach, B. Brożek, W. Załuski (eds.), Dziesięć wykładów o ekonomii prawa, Wolters Kluwer, Warszawa 2007, p. 25.

7 P.A. Samuelson, W.D. Nordhaus, Ekonomia. Vol. 1. PWN, Warszawa 2004, p. 443. 
Legal solutions gain hallmarks of efficiency if the goal set by the legislator is realized ${ }^{8}$. In line with the assumptions of the Virginia school, the legislators' rational reflexes in the form of their own individual interest, should not be excluded.

Pareto efficiency is also called allocative efficiency. In this approach, a condition in which the improvement of the situation of an individual in a given population will not change the welfare of other members should be considered economically effective. A reverse situation, that is improvement of welfare of the participants of the population at the expense of even one person is not an efficient move. Pareto optimality is merely a theoretical construct, an excellent introduction to empirical research ${ }^{9}$. This category reflects the energy efficiency rule applied in physics and mechanics and, therefore, owing to its static aspect, there are serious difficulties in its referencing to the social institutions of the dynamic nature ${ }^{10}$.

Usually, as a result of the introduction of a specific legal regulation, someone gains and someone loses. Even when taking interpersonal relationships into account. The amelioration of the situation of one person, causing jealousy in other participants of a population, may be treated as a deterioration of their position $^{11}$. For this reason, according to its opponents, Pareto efficiency, in an attempt at its practical use, leads to a complete decision-making paralysis ${ }^{12}$.

The Kaldor-Hicks economic efficiency, which is a development of the Pareto optimality, accepts deterioration of the members of a particular group of the population only if the modification which a solution causes brings disproportionately large benefits for the rest of the participants in the social reality. These benefits, even after offsetting potential losses, still need to have a positive net effect. Repair of damage, however, is not necessary, but only possible. The criterion under consideration forms a theoretical background for the cost-benefit analysis ${ }^{13}$. This analysis consists in the consideration of the options available in a particular situation, by making a profit and loss balance of each. The purpose of such a juxtaposition is to help make the best decision.

${ }^{8}$ J. Stelmach, B. Brożek, W. Załuski, op. cit., p. 26.

9 S. Czech, Ekonomia dobrobytu a pañstwo opiekuńcze - relacja przesztości czy przysztości?, „Studia ekonomiczne - Zeszyty naukowe”, No. 176/2014, p. 58.

10 J.H. De Soto, Sprawiedliwośc a efektywnośc, Fijorr Publishing Company, Warszawa 2010, pp. 9-23.

${ }^{11}$ Ibidem, p. 21.

${ }^{12}$ J. Stelmach, B. Brożek, W. Załuski, op. cit., p. 31.

13 A.K. Dasgupta, D.W. Pearce, Cost-Benefit Analysis: Theory and Practice, Palgrave Macmillan, London 1972. 
The choice of a maximization measure in the application of the KaldorHicks efficiency criterion in relation to legal regulations is a problem. The utilitarian concept, effective in this regard, is very difficult to apply in practice. Therefore, it gives way to wealth maximization, that is monetary maximization $^{14}$. Opponents also accuse the discussed criterion of logical inconsistency and coercion in order to obtain permission to make changes from entities exposed to harm as a result of a given solution ${ }^{15}$.

Consistently with the marginal analysis approach, legal regulations are economically effective when pursuing a socially desirable goal, only up to a certain point - the point at which the marginal social costs are levelled with their marginal benefits ${ }^{16}$. This means that the solutions are economically efficient only up to a certain level above which they generate losses. For example, no officer has been hired in a city. Employment of the first one will bring a large increase in benefits, just like recruitment of a second, third and fourth one. In contrast, an increase in benefits over costs at the employment of the one-hundred fiftieth one will not be as high, and it may be that it will be the level at which the marginal social benefits level with costs. Employment of each additional officer will, in this case, be economically inefficient, and will bring unnecessary costs.

Research into economic efficiency in terms of marginal analysis as proposed by law and economics, turns out to be useful for optimizing the decision-making process. A disadvantage of this approach consists in its inability to implement the adopted goal in full, because at some point its implementation becomes inefficient. Following this path, it can be concluded that, for example, complete elimination of crime is not economically justified. This method, however, will be helpful, and will not hinder the process of decision-making. Performing a similar analysis will show a new point of view, expand the research perspective and force one to think about the significance of the introduction or the changing of certain legal institutional solutions.

\subsection{TENSIONS BETWEEN EFFICIENCY AND JUSTICE}

Justice and economic efficiency are linked by the problem of scarcity of resources. If they were endless, people would not diminish their quanti-

${ }^{14}$ A. Nowak-Gruca, Cywilnoprawna ochrona autorskich praw majątkowych w świetle ekonomicznej analizy prawa, Wolters Kluwer, Warszawa 2013, p. 46.

${ }^{15}$ R. Boadway, The Welfare Foundations of Cost-Benefit Analysis, „Economic Journal”, Vol. 84, No. 336/1974, pp. 926-939.

${ }_{16}$ J. Stelmach, B. Brożek, W. Załuski, op. cit., p. 37 and A. Nowak-Gruca, op. cit., p. 47. 
ty by their own activity; then the phenomenon of efficient management and injustice would become purely theoretical concepts, having no raison d'être. The reality, however, is different.

Just as the architect cannot use the same tools in the design of a variety of buildings or structures, so the legislature, while creating and evaluating legal regulations, cannot rely on a once adopted, seemingly effective criterion. In both the situations referred to, there is no single correct solution, proving effective in every situation. Today's reality undergoes dynamic social, technological, and political changes which must be followed, or even preceded by the law. It cannot be that all areas of life are developing, and the law is still stuck at the same point. This specific situation should be a source for the need for justice alongside other, often equally important, criteria for interpretation.

J. Stelmach put forward an interesting argument in this regard. In his opinion, "a law that does not meet even the "minimum" conditions of efficiency (although formally in force) actually ceases to exist"17. He adds that "systems of law based solely on lawmaking are not effective" 18 . It is worth considering the effects legal regulations cause in the socio-economic area. They should not be an obstacle, limiting growth in every area of life to which they relate. In this way, they never will guard justice - its fundamental value.

It follows from the previous considerations that there is no single universal definition of economic efficiency. Similarly, the creation of an objective theory of justice can pose great difficulty but, as it turns out, it is not impossible. Israel M. Kirzner, a representative of the Austrian school of economics, proposed an idea of distributive justice which could be applied in the capitalist system. He believes that economic theory should be considered in dynamic terms ${ }^{19}$ (and not as up to now, in static terms) and also devoid of value judgments. This makes it possible to achieve clear ethical attitudes and makes logical-deductive inquiries free from many errors, becoming thus more acceptable on the basis of social ethics. In this sense, "efficiency" and "justice" would not only be a compromise, because justice is the only way to efficiency and vice versa: efficient solutions should be considered fair. These categories do not stand in opposition to each other, as might have appeared earlier, but complement each other ${ }^{20}$.

17 Stelmach J., Efektywne prawo, http://www2.wpia.uw.edu.pl/files/doktoranckie/ STELMACH\%20J.\%20-\%20EFEKTYWNE\%20PRAWO.doc?short (18.01.2015).

18 Ibidem.

${ }^{19}$ Contemporary economic reality is so dynamic and diverse that it is becoming impossible to put it into a rigid mathematical formula.

${ }^{20}$ J.H. De Soto, op. cit., pp. 337-339. 


\subsection{THE IMPORTANCE OF LAW AND ECONOMICS IN CONTEMPORARY ECONOMIC REALITY}

Given the fact that the incompatibility between "efficiency" and "justice" may be only apparent, another issue is also worth considering. The law has a big impact on the surrounding world, including economic reality. Therefore, it seems that attempts at levelling the differences between the legal and actual realities are not without significance. A dissonance between them is particularly pronounced in the judicial process. For example, a trader acquitted by the court in a fiscal case may be in fact guilty of the alleged offence. The reason for such state of affairs is a number of principles of interpretation and axiological rules used by lawyers.

It is generally accepted that the fundamental purpose of the law, materializing substantially during the trial, is to arrive at the truth. However, this is not the objective truth, but the judicial truth, exerting its impact on the actual reality.

The task of jurisprudence is the creation of a system of expected behaviours of people, including judges ${ }^{21}$. This thesis is supported by the work of Holmes as early as 1897. In his opinion: "for the rational scholarship of law a careful (conscientious) interpreter can be man of today, but man of the future is a statistician and master of economics"22.

Economics is a social science dealing with the problem of scarcity of resources. This scarcity prevents a full satisfaction of human needs. One of the essential elements of the concept of economic rationality is the taking into account of changes occurring in the market environment. These changes are undoubtedly under the influence of the law. It regulates human behaviour and is an important aspect of the decisions taken by business entities.

It is also worth noting that the dialectical struggle does not take place in the present day on the line of capital - work, but on that of a company - the state. The government becomes an enemy of modern business organizations, owing to the fact that it reflects the interest of voters belonging to various social groups. The actions that are taken on their behalf are not always favourable for business ${ }^{23}$. In particular, legal regulations are recognized as one of the most important obstacles to doing business by Polish companies. In the first place there are undoubtedly fiscal regulations, with a high impact on the real costs of the conducted business activity. Owing to

${ }^{21}$ Cf. J. Stelmach, Spór o ekonomicznq analizé prawa, [in:] J. Stelmach, M. Soniewicka (ed.), Analiza ekonomiczna w zastosowaniach prawniczych, Wolters Kluwer, Warszawa 2007, p. 10.

22 O.W. Holmes, The Path of Law, New York 2003, p. 694.

23 J.K. Galbraith, Ekonomia w perspektywie, PWE, Warszawa 1992, pp. 296-313. 
the rapidly changing market environment businesses must have a quick response which is slowed down by excessively lengthy procedures provided for in the official rules. The law may not be abstracted from the socio-economic reality of the country in which it is enforced. Otherwise, it will become a great place for pathology and numerous abuses, destroying the creativity of modern entrepreneurs.

\section{THE RESULTS OF RESEARCH}

Man is the creator of the law, however, the law has become independent from the legislator and often has an opposite effect to that intended. Because of the need to bring the law into the practice of commercial life, there is a need to reform the traditional approach to legal norms and methods of interpretation through the tools proposed by the representatives of law and economics.

Economic arguments should not always be in the lead in the process of justifying judgements, including those in the field of economic matters. However, the reaching for them by participants in the legal discourse often means a departure from the learned interpretive tradition, the opening of jurisprudence to other fields of learning and admits the proper shape of a final settlement (economically effective).

The taking into account by the legislature of the scarcity of resources, particularly in relation to economic life, can have a significant impact on the efficient allocation of goods belonging to modern enterprises, and consequently on the achievement of social welfare.

\section{CONCLUSIONS}

Considerations of the representatives of the law and economics movement are not purely of a theoretical nature. The contemporary economic reality undergoes dynamic changes which must be followed, and even preceded by the existing legal regulations. Effective interpretation of the law requires the extension of the existing catalogue of methods of interpretation by those tools used so far only in the field of the economic sciences. It makes it possible to extend the research perspective, and forces a reflection on the meaning and impact of the legislation in force. The legislature should not remain indifferent to the problem of scarcity, either. Legal regulations should promote the efficient allocation of goods, so that it becomes possible to achieve social 
welfare. In addition, effectiveness, as one of the essential principles of the presented movement, need not always stand in opposition to justice, the basic value of the law. These categories should be mutually supportive and become guarantors of each other.

\section{BIBLIOGRAPHY}

Baird D., Gertner R., Picker R., Game Theory and the Law, Harvard University Press, 1998.

Boadway R., The Welfare Foundations of Cost-Benefit Analysis, „Economic Journal”, Vol. 84, No. 336/1974, http://dx.doi.org/10.2307/2230574.

Cooter R., Ulen T., Ekonomiczna analiza prawa, C.H. Beck, Warszawa 2011.

Czech S., Ekonomia dobrobytu a państwo opiekuńcze - relacja przesztości czy przysztosci?, „Studia Ekonomiczne - Zeszyty Naukowe”, No. 176/2014.

Dasgupta A.K., Pearce D.W., Cost-Benefit Analysis: Theory and Practice, Palgrave Macmillan, London 1972, http://dx.doi.org/10.2307/2553062.

De Soto J.H., Sprawiedliwość a efektywność, Fijorr Publishing Company, Warszawa 2010.

Ehrlich S., Wstęp do nauki o państwie i prawie, PWN, Warszawa 1971.

Galbraith J.K., Ekonomia w perspektywie, PWE, Warszawa 1992.

Gaweł T., Klimczak M., Pojęcie instytucji w prawie i ekonomii, „Ekonomia i Prawo”, Vol. 1, No. 1/2005.

Golecki M.J., Między pewnościq a efektywnościa. Marginalizm instytucjonalny wobec prawotwórczego stosowania prawa, Wolters Kluwer, Warszawa 2011.

Holmes O.W., The Path of Law, New York 2003.

Kalka K., Sprawiedliwość i sprawności spoteczne wedtug śrw. Tomasza z Akwinu, Wydawnictwo Uczelniane WSP w Bydgoszczy, Bydgoszcz 1994.

Nowak-Gruca A., Cywilnoprawna ochrona autorskich praw majątkowych w siwietle ekonomicznej analizy prawa, Wolters Kluwer, Warszawa 2013.

Samuelson P.A., Nordhau W.D., Ekonomia. Vol. 1. PWN, Warszawa 2004.

Stelmach J., Brożek B., Załuski W., Ekonomiczna efektywność, [in:] J. Stelmach, B. Brożek, W. Załuski (eds.), Dziesięć wyktadów o ekonomii prawa, Wolters Kluwer, Warszawa 2007.

Stelmach J., Efektywne prawo, http://www2.wpia.uw.edu.pl/files/doktoranckie/STELMACH\%20J.\%20-\%20EFEKTYWNE\%20PRAWO.doc?short= (18.01.2015).

Stelmach J., Spór o ekonomicznq analize prawa, [in:] J. Stelmach, M. Soniewicka (ed.), Analiza ekonomiczna w zastosowaniach prawniczych, Wolters Kluwer, Warszawa 2007. 
